\title{
Why are aggregate equity payouts pro-cyclical?
}

\author{
Winifred Huang-Meier ${ }^{\mathrm{a}, *}$, Mark C. Freeman ${ }^{\mathrm{b}}$ and Khelifa Mazouz ${ }^{\mathrm{c}}$
}

\author{
a Aston Business School, Aston University, Birmingham, B4 7ET, United Kingdom \\ ${ }^{\mathrm{b}}$ School of Business and Economics, Loughborough University, Leicestershire, \\ LE11 3TU, United Kingdom \\ ${ }^{\mathrm{c}}$ Cardiff Business School, Cardiff University, Aberconway Building, Colum Drive \\ Cardiff, CF10 3EU, United Kingdom \\ * Corresponding author. Tel.: +44 121204 3490; fax: +44 1212044915 \\ E-mail addresses: w.huang-meier@aston.ac.uk (W. Huang-Meier), \\ m.c.freeman@1boro.ac.uk (M.C. Freeman), mazouzk@cardiff.ac.uk (K. Mazouz)
}

\begin{abstract}
We use two general equilibrium models to explain why changes in the external economic environment result in pro-cyclical aggregate dividend payout behavior. Both models that we consider endogenize low elasticity of investment. The first model incorporates capital adjustment costs, while the second one assumes that risk-averse managers maximize their own objective function rather than
\end{abstract}


shareholder wealth. We show that, while both models generate pro-cyclical aggregate dividends, a feature consistent with the observed business-cycle pattern of payouts from well-diversified portfolios, the second model provides a more likely explanation for this effect. Our findings emphasize the importance of incorporating agency conflicts when considering the relationship between the external economic environment and the financial behavior of businesses.

Keywords: dynamic stochastic general equilibrium economies; payout policy; business fluctuations; firm objectives; capital adjustment costs

$J E: \mathrm{C} 63, \mathrm{C} 68, \mathrm{G} 35, \mathrm{E} 32, \mathrm{~L} 21, \mathrm{E} 22$

\section{Introduction}

The observed correlation coefficient between the real aggregate dividends paid by firms and real GDP in the U.S. has been around +0.50 for many years. ${ }^{1}$ This phenomenon suggests that the payout policies of businesses are systematically and strongly affected by external changes in the economic environment. However, this clearly observed aggregate dividend pro-cyclicality is inconsistent with the

\footnotetext{
${ }^{1}$ The observation period is between 1984 and 2010. For more details, please refer to Table 1 below.
} 
predictions of large parts of the existing theoretical literature. ${ }^{2}$ Many general equilibrium models imply that investors should benefit from holding a portfolio with counter-cyclical equity payouts (e.g., Alessandrini, 2003; Carceles-Poveda, 2009; Jermann and Quadrini, 2012). These predictions arise because, in economic booms, many potentially profitable investment opportunities are available to firms who wish to reinvest. In addition, since the marginal utility of consumption is low during strong economic conditions, investors are less likely to depend on dividend income at this time.

In this paper, we describe two dynamic stochastic general equilibrium (DSGE) models to explain why external changes in the economic environment should result in pro-cyclical aggregate equity payout behavior. We model an environment where firms and households simultaneously undertake constrained optimizations and market clearing conditions ensure that the economy remains in equilibrium. As a consequence, dividend and investment decisions are made simultaneous and neither is a 'residual' of the other.

In the first set of models, managers aim to maximize their current share price while firms experience capital adjustment costs. This follows an extensive literature that is based on the observation that managers cannot immediately and perfectly adjust their real investment decisions (see, e.g., Jermann, 1998; Boldrin

\footnotetext{
${ }^{2}$ This issue is distinct from optimal firm-level payout behavior, which is the focus of attention in much of the dividend policy research in financial economics; see, for example, Bhattacharyya (2007) for a review of that field.
} 
et al., 2001; Cooper and Haltiwanger, 2006; Gershun, 2010; Santoro and Wei, 2011). This investment friction has previously played an important role in explaining a number of asset pricing phenomena based upon DSGE models. Both Jermann (1998) and Danthine and Donaldson (2002) have exploited it to present potential resolutions to the equity premium puzzle. Christiano and Fisher (1995), by contrast, apply adjustment costs to Tobin's Q and show that adjustments costs are related to the cyclical properties of equity prices and investment goods.

In our second set of models we assume that there are no frictions, but agency conflicts exist. Specifically, we assume that managers maximize their own expected utility function rather than shareholders' wealth (see, inter alia, Radner, 1970; Sandmo, 1971; Leland, 1972; Carceles-Poveda, 2005, 2009). This choice exploits the known similarity between models that incorporate risk-averse managers and those with capital adjustment costs. In particular, Carceles-Poveda (2003) has shown that, with appropriately matched parameter values, the equilibrium behavior of these two economies around the steady state is identical.

A common key feature among these models is that they endogenize low elasticity of investment. When this feature is combined with investors' desire for dividend income as a source of consumption, more (less) money becomes available to pay out to shareholders in economic booms (recessions). This prediction is consistent with observed market behavior. Thus, since both our models endogenize 
low elasticity of investment, if one model predicts pro-cyclical dividends then so should the other; we confirm that here. However, we also show that the cyclicality of optimal dividend behavior is clearly distinct between the two models and, as a consequence, each is not equally plausible as an explanation. We find that while the required level of managerial risk aversion falls at the lower end of standard ranges, relatively high levels of capital adjustment costs are required to explain observed payout and consumption behavior. This evidence suggests that the economy with risk-averse managers offers a more realistic explanation to the dividend pro-cyclicality phenomenon. This conclusion is supported by the observation that the agency conflict model results are more robust to changes in the choice of parameter values.

In order to test the overall performance of our DSGE models, we consider their explanatory power for a set of macroeconomic variables. This captures the pro-cyclicality and volatility of four variables: dividends, consumption, labor hours worked, and investment. The performances of the preferred specifications across the entire range of these diagnostics are the best amongst all the models considered. Resolving the anomaly of pro-cyclical aggregate dividends through either agency conflicts or capital adjustment costs comes with the additional benefit of increasing the overall ability of these models to explain the broader macroeconomy.

This paper is most naturally compared with important recent studies by Carceles-Poveda (2009) and Jermann and Quadrini (2012). Carceles-Poveda 
(2009) focuses on the sensitivity of aggregate behavior to household heterogeneity in an incomplete market economy both in the presence and absence of utility maximizing managers. Jermann and Quadrini (2012), by contrast, explain procyclical equity payments through economy-wide financial shocks. We present a number of new findings. First, we show that the pro-cyclicality of dividends can be explained in simple agency-conflict models with representative agents and no frictions. Second, we demonstrate that agency conflicts are more likely to resolve the dividend cyclicality puzzle than capital adjustment costs. Third, we extend the representative household's utility function to allow for the presence of internal multiplicative habit formation; a feature that generally makes household consumption smoother (see, for example, Constantinides, 1990). Finally, we present detailed sensitivity analysis that demonstrates that the pro-cyclicality of dividends will emerge in the utility maximizing manager model for a wide range of plausible parameter values.

The remainder of the paper is structured as follows. Section 2 presents the economic environment of the utility-maximizing manager, the value-maximizing firms with capital adjustment costs, and the "basic" model that has neither of these features. Section 3 reports our findings and Section 4 concludes. 


\section{Economic Environment}

This section presents two economic models that can potentially explain the procyclicality of aggregate payout policy. The first model is based on a valuemaximizing firm with capital adjustment costs (VM-CAC hereafter), while the second one assumes that managers maximize their own objective function rather than shareholders' wealth (UM hereafter). We initially present the assumptions that both models have in common and then introduce the differences.

\subsection{The Firm and Household}

The tax-free economy consists of a representative firm that is all-equity financed with one share in issue and a representative agent. There are no other investment opportunities available and, with the exception of capital adjustment costs in the VM-CAC model, there are no frictions. ${ }^{3}$

At any given time, $t$, the output, $Y_{t}$, from the representative firm is given by a standard Cobb-Douglas production function that depends on both the capital, $K_{t-1}$, and normalized labor hours, $L_{t}$, employed:

$$
Y_{t}=Z_{t} \mathrm{f}\left(K_{t-1}, \mathrm{x} L_{t}\right)=Z_{t} K_{t-1}^{\alpha}\left(\mathrm{x} L_{t}^{d}\right)^{1-\alpha}
$$

\footnotetext{
${ }^{3}$ With the exception of all-equity financing, these assumptions are identical to Jermann and Quadrini (2012).
} 
where $Z_{t}$ and $\mathrm{x}$ denote a stochastic technology shock and the deterministic trend in labor augmenting technical change respectively. The parameters $\alpha$ and $1-\alpha$ are output elasticities of capital and labor, respectively. ${ }^{4}$ The $d$ superscript on $L_{t}^{d}$ denotes a firm's demand for labor. The technology shock process is assumed to follow a first order autoregressive process $(\mathrm{AR}(1))$ in logs and evolves exogenously as follows: $\ln Z_{t}=\psi \ln Z_{t-1}+\varepsilon_{t}$, where $\psi$ is the parameter of persistence and $\varepsilon_{t}$ is an independent and identically normally distributed random variable $\varepsilon_{t} \sim N\left(0, \sigma_{\varepsilon}^{2}\right)$. The representative firm also pays dividends, $D_{t}$, to equity owners:

$$
D_{t}=Y_{t}-W_{t} L_{t}^{d}-I_{t}
$$

where $W_{t}$ is the wage rate and $I_{t}$ is the amount re-invested by the firm. ${ }^{5}$ By controlling for the initial inputs $K$ and $L$, other variables (equity payouts, output and investment) are simultaneously endogenized along with the household's problem.

Many DSGE models are built with a time-separable utility function, which assumes that the representative household's preferences are independently determined by consumption and leisure in each period. In addition, the

\footnotetext{
${ }^{4}$ See also Jermann (1998) for more details on the specification of the firm's production function.

${ }^{5}$ See, for example, Lang and Litzenberger (1989), Alli et al. (1993) and Baker and Smith (2006).
} 
representative's utility that is derived from current consumption is independent of past consumption behavior. In line with Constantinides (1990) and others, we extend the utility function to incorporate internal habit formation. ${ }^{6}$ In this case, the representative household's level of satisfaction from consumption is determined not only by current consumption but also by past consumption.

Constantinides (1990) shows that this feature resolves Mehra and Prescott's (1985) equity premium puzzle and generally results in smoother optimal household consumption patterns. In this case, the household's objective function $\Psi_{H, t}$ is:

$$
\Psi_{H, t}=\max _{C_{t}, L_{t}^{S}, N_{t}} E_{t}\left[\sum_{h=0}^{\infty} \beta^{h} \frac{\left[\left(C_{t+h}-\xi C_{t+h-1}\right)^{\rho}\left(1-L_{t+h}^{S}\right)^{1-\rho}\right]^{1-\gamma}}{1-\gamma}\right]
$$

for $0 \leq \xi, \gamma ; 0<\rho<1$. $C_{t}$ is the consumption of the household, $\rho$ determines the time devoted to market activities (Campbell, 1994 and Cooley and Prescott, 1995), $L_{t}^{S}$ denotes the hours worked, $\xi$ determines the strength of the habit motive and $\gamma$ is the coefficient of relative risk aversion (CRRA) of the household. The $s$ superscript on $L_{t}^{S}$ denotes the supply of labor. $\beta$ is the time discount factor. Labor hours worked are normalized so that $1-L_{t}^{S}$ denotes the time available for leisure.

\footnotetext{
${ }^{6}$ See, for example, Constantinides (1990), Carroll (2000), Carroll et al. (2000), Dynan (2000), Boldrin et al. (2001), Seckin (2001), Otrok et al. (2002), Gershun (2010) among others.
} 
In this framework, consumption comes from two sources. First, the household receives labor income of $W_{t} L_{t}^{S}$. Second, it can choose to hold $N_{t}$ shares in the representative firm. Cash can then be generated from this equity holding both from the dividend $D_{t} N_{t-1}$ and by selling shares at the market price $Q_{t}$. The household budget constraint determines this price of equity:

$$
\mathrm{C}_{t}=W_{t} L_{t}^{S}+D_{t} N_{t-1}+\left(N_{t-1}-N_{t}\right) Q_{t}
$$

\subsection{The Manager Objective Function and the Capital Accumulation Process}

Differences between the "basic" model, the UM model, and the VM-CAC model arise from the managers' objective function, $\Psi_{F, t}$, and the process that determines the evolution of capital within the firm.

Managers have control over two variables $\left(L^{d}\right.$ and $\left.K\right)$ at any time, $t$, to maximize their objective function. In both the "basic" and VM-CAC models, the assumption is that managers aim to maximize shareholder wealth, $Q_{t}$. By contrast, following Radner (1970), Sandmo (1971) and Leland (1972), among others, the UM model is based on the assumption that managers are risk-averse and act in a way that satisfies their own personal objective function rather than maximizing the share price of their firm. Carceles-Poveda $(2005,2009)$ shows that the risk aversion 
assumption improves our understanding of managers' behavior. We summarize the manager's objective function as:

$$
\Psi_{F, t}=\left\{\begin{array}{lr}
\max _{L_{t}^{d}, K_{t}} E_{t}\left[\sum_{h=0}^{\infty} \phi^{h} \frac{D_{t+h}^{1-\gamma_{F}}-1}{1-\gamma_{F}}\right], & \mathrm{UM} \\
\max _{L_{t}^{d}, K_{t}} Q_{t}, & \mathrm{VM}-\mathrm{CAC}
\end{array}\right.
$$

where $\gamma_{F}$ is the coefficient of relative risk aversion of the manager and $\phi$ is the subjective discount factor. This is an appropriate utility function if managers' income comes solely from income derived from the ownership of equity in his/her own firm. ${ }^{7}$ There is some support for this from studies, which show how poorly diversified entrepreneur's portfolios often are; e.g., Heaton and Lucas (2000). Alternately, we might imagine that the manager is rewarded though a salary and bonus policy that is linked to the firm's dividend payouts. This managerial utility function has previously been used by Carceles-Poveda (2003).

The second key difference between the "basic" model, the UM model, and the VM-CAC model is related to the capital accumulation process. In the "basic" and UM models, the capital employed in the firm develops according to $K_{t}=$

\footnotetext{
${ }^{7}$ While, under this assumption, the manager's salary comes entirely from dividends, it is also necessary to assume that the manager holds an infinitesimally small fraction of the equity. This is because, within this model, all dividends go to the household. We thank an anonymous referee for this point.
} 
$(1-\eta) K_{t-1}+I_{t}$, where $\eta$ denotes the capital depreciation rate. By contrast, in the VM-CAC model, the capital accumulation process is given by

$$
K_{t}=(1-\eta) K_{t-1}+g\left(I_{t}, K_{t-1}, \eta, \zeta\right) K_{t-1}
$$

where $g(\cdot)$ is a concave capital adjustment cost function and $\zeta$ determines the level of capital adjustment costs. Given this economic friction, the elasticity of investment is expected to be lower than in a model without CAC. Specifically, we follow Gershun (2010) and set

$$
g\left(I_{t}, K_{t-1}, \eta, \zeta\right)=\frac{\eta^{1 / \zeta}}{1-\frac{1}{\zeta}}\left(\frac{I_{t}}{K_{t-1}}\right)^{1-1 / \zeta}+\frac{\eta}{1-\zeta}
$$

Notice that, the lower the value of $\zeta$, the higher the capital adjustment cost. Ultimately, as $\zeta \rightarrow \infty$, the capital adjustment cost goes to zero and the VM-CAC model becomes the "basic" model. We refer to this last case as the "VM-no-CAC model".

\subsection{Equilibrium Conditions}

General equilibrium exists in this economy when both the firm and the household are able to simultaneously maximize their objective functions. This leads to five first-order conditions that can be algebraically rearranged to give: 


$$
1=\left\{\begin{array}{c}
E_{t}\left(\phi\left(\frac{D_{t}}{D_{t+1}}\right)^{\gamma_{F}}\left(Z_{t+1} \frac{\partial f}{\partial K_{t}}+1-\eta\right)\right), \quad \mathrm{UM} \\
\frac{\partial g}{\partial I_{t}} K_{t-1} E_{t}\left[M_{t+1}\right]\left(Z_{t+1} \frac{\partial f}{\partial K_{t}}+\frac{1-\eta+g+K_{t} \frac{\partial g}{\partial K_{t}}}{K_{t} \frac{\partial g}{\partial I_{t}}}\right), \mathrm{VM}-\mathrm{CAC} \\
W_{t}=(1-\alpha) \frac{Y_{t}}{L_{t}} \\
Q_{t}=E_{t}\left[M_{t+1}\left(Q_{t+1}+D_{t+1}\right)\right]
\end{array}\right.
$$

where $M_{t+h}=\left(\frac{\partial \Psi_{H, t}}{\partial C_{t+h}}\right) /\left(\frac{\partial \Psi_{H, t}}{\partial C_{t}}\right)$ is the household's inter-temporal marginal rate of substitution of consumption between times $t$ and $t+h$. Notice that the last of these equations is just the standard Euler equation that is used widely in asset pricing.

In addition to these conditions, labor and capital markets must clear. This leads to three further constraints. First, the supply and demand of labor must be equal, $L_{t}^{S}=L_{t}^{d}$. Second, the firm has one share in issue at all times, $N_{t-1}=1$. Finally, output must be either consumed or re-invested, $Y_{t}=C_{t}+I_{t}$.

To simultaneously solve this set of six equations, we use Dynare software in conjunction with Matlab. This allows us to determine the steady state growth rates of several underlying macroeconomic and financial variables, together with a 
variance-covariance matrix of the growth rates of each of these variables, and impulse response functions. ${ }^{8}$

\subsection{Calibration}

This subsection describes the parameter values used in our baseline calibrations. Further evidence on the sensitivity of our results to the parameter values is provided in subsection 3.1 .

For the Cobb-Douglas production function, the values of the capital elasticity of output $\alpha=0.36$, the depreciation rate $\eta=0.025$, and the quarterly trend in labor augmenting technical change $\mathrm{x}=1.005$ are taken from Kydland and Prescott (1982) and Jermann (1998). These values are also commonly used in longterm economic and finance models (e.g. Hansen, 1985; Campbell, 1994; Jermann, 1998). In line with Hansen (1985), the stochastic technology shock $(Z)$ follows an $\operatorname{AR}(1)$ process with a persistence parameter $\psi=0.95$ and standard deviation $\sigma_{\varepsilon}=$ 0.00712 .

For the household, we choose $\beta=0.99$, which is standard in the literature (e.g. Hansen, 1985; Prescott, 1986; Campbell, 1994; and Jermann, 1998). We follow Carceles-Poveda (2003) by setting $\gamma=1.44$. The value of $\gamma$ falls within the 1 to 5 range, which is again generally considered reasonable by many economists (e.g. Jermann, 1998; Carceles-Poveda, 2003; and Gershun, 2010). In the sensitivity

\footnotetext{
${ }^{8}$ The impulse response functions are available on request from the authors.
} 
analysis, we vary $\gamma$ between 0 and 100. The estimated value of the agent's internal consumption habit persistence parameter $\xi=0.82$ is equivalent to the figure estimated by Jermann (1998). The value $\rho=0.36$ for the time devoted to market activities is obtained from Campbell (1994). ${ }^{9}$

Following Carceles-Poveda (2003), we set manager's stochastic subjective discount factor to $\phi=0.99$. We also set the manager's risk aversion coefficient to $\gamma_{F}=1.25$ and 5 to indicate low and high levels of risk aversion, respectively. Both these risk aversion values lie within the one to five range that many economists consider to be realistic (e.g., Ljungqvist and Sargent, 2004; Parrino et al., 2005; and An and Cheung, 2010). We also vary this figure between 0 and 100 to examine the sensitivity of dividend cyclicality to the manager's degree of risk aversion.

In the VM-CAC economy, the parameter value determining capital adjustment costs is set to (1) $\zeta=40$ for relatively low capital adjustment costs

\footnotetext{
${ }^{9}$ Because of the concavity of the CAC function, it is more costly to adjust the investmentto-capital ratio upwards than adjust it downwards. It should be noted that CACs are not always considered in the function of capital accumulation but can instead be captured in the goods clearing condition. This is because some scholars assert that the influence of capital adjustment costs is on the amount of output, not the amount of capital. For the case of not putting capital adjustment costs in the capital accumulation process, see Danthine and Donaldson (2002). For papers considering capital adjustment costs in the function of the capital accumulation process, see, for example, Danthine and Donaldson (2002), Canzoneri et al. (2006), Collard and Dellas (2006) and Gershun (2010).
} 
following Gershun (2010) and (2) $\zeta=0.30$ for relatively high capital adjustment costs, which is similar to the value used by Jermann (1998).

\section{Results}

We report the results for six models, each both with $(\xi=0.82)$ and without $(\xi=$ 0 ) household habit formation, giving a total of twelve models. The first is the "basic" VM-no-CAC economic framework with no capital adjustment costs and a manager who aims to maximize shareholder wealth; this is the standard DSGE model. The next three models are for the utility maximizing (UM) manager with different levels of risk aversion; risk neutrality $\left(\gamma_{F}=0\right)$ and both low $\left(\gamma_{F}=\right.$ 1.25) and high $\left(\gamma_{F}=5\right)$ risk aversion. The final two models are low $(\zeta=40)$ and high $(\zeta=0.30)$ capital adjustment cost VM-CAC models.

In Table 1 we report eight summary statistics for each model. These refer to the cyclicality and volatility of dividends, consumption, labor hours, and investment. The former considers the correlation between the growth of each variable and GDP growth. The latter is the standard deviation of each variable after it has been normalized by GDP. This table also reports the observed U.S. 
macroeconomic statistics from 1984:1 to 2010:2, with all data detrended with a Hodrick-Prescott filter. ${ }^{10}$

\section{Insert Table 1 about here}

It is clear that the basic VM-no-CAC model fails in a wide variety of ways. Most crucially from this paper's perspective, optimal equity payout behavior is predicted to be strongly counter-cyclical; -0.96 and -0.98 in the presence and absence of habit formation, respectively. This feature has also been reported in prior studies (see, for example, Alessandrini, 2003; Carceles-Poveda, 2009 and Jermann and Quadrini, 2012). However, this finding contrasts sharply with observed payout policy, which indicates a correlation between real equity payouts and real GDP of $+50 \%$ for the period 1984:1-2010:2. For the other three variables, the predicted correlation is relatively close to the observed levels, except for consumption when the household has a habit formation utility function. The basic

10 The data we use are taken from Jermann and Quadrini (2012)'s technical appendix which is online at the American Economic Review website. Their data are obtained from the Flow of Funds Accounts of the Federal Reserve Board (FFA) and the National Income and Product Accounts (NIPA). Real GDP and consumption of non-durables and services are obtained from NIPA Table 1.1.3. Equity payout is the net value of "net dividends (Nonfinancial Corporate Business, F.102, line 3) minus the total of "net new equity issue" (Nonfinancial Corporate Business (F.102, line38). All data are seasonally adjusted and detrended with a band-pass filter that preserves cycles of 1.5-8 years with 12 lags suggested by Baxter and King (1999). The band-pass filter codes can be found at Kanda Naknoi's website: http://www.krannert.purdue.edu/faculty/knaknoi/Econ635/matlab_filter.html. 
model also predicts dividends that are too volatile, while consumption, investment and labor hours are too smooth. Changing the model to incorporate a risk-neutral manager only makes matters worse for a number of diagnostics, including the fact that consumption is now predicted to be countercyclical.

When we introduce either (i) relatively low levels of risk aversion for managers, $\gamma_{F}=1.25$, and a household either with or without habit formation, or (ii) high capital adjustment costs, $\zeta=0.30$, when investors have habit formation, then we derive a much better understanding of dividend cyclicality. In each case, the correlation between equity payout growth with GDP growth is extremely similar to that observed in the real data. This is consistent with Carceles-Poveda (2009) for the UM model, although we do not rely here on incomplete markets and heterogeneous agents.

The intuition behind this result is that, as shown by Carceles-Poveda (2003), with either risk-averse managers or $\mathrm{CAC}$, investment becomes less volatile. In economic booms, risk-averse managers may be less inclined to place money in projects with uncertain future equity payouts in case the state of the economy changes while high capital adjustment costs make it less attractive for managers to re-invest. These arguments suggest that firms may have more incentive to pay out cash in the form of dividends when profits are high, which helps reconcile the theory with the observed data. 
We further notice from Table 1 that the cyclical behavior of equity payouts is sensitive to managerial risk aversion and CAC. With low CAC, for example, optimal equity policy remains countercyclical, while for high levels of managerial risk aversion, optimal dividend policy is too pro-cyclical. We therefore concentrate on three models: low levels of managerial risk aversion $\left(\gamma_{F}=1.25\right)$ both with and without habit, and high $\mathrm{CACs}(\zeta=0.30)$ with habit.

When considering the broader macroeconomy, each of these three models has different strengths and weaknesses. The presence of habit formation helps to better explain the volatility of hours worked but cannot capture this variable's procyclicality. The VM-CAC model captures better the volatility of dividend payments when compared to the UM specifications. By contrast, the UM models slightly better explain the volatility of investment, although this remains too low in all cases.

Given the differences in performance of the twelve different models across each of the eight diagnostics considered, we construct three meta-statistics to better understand their relative overall performance. First, for each model, we calculate the average absolute difference between the predicted and observed correlations between dividends, consumption, labor hours and investment with GDP. This average is termed the "Correlation Error". We also calculate the absolute difference between the predicted and observed standard deviation of these variables when normalized by GDP. These are then standardized by the observed standard 
deviation in each case before being averaged; this is referred to as the "Standard Deviation Error". The final meta-statistic, "Total Error", for each model is then the average of the correlation and standard deviation errors. Results are reported in Table 2.

Insert Table 2 about here

We can see that five models perform poorly as they are in the bottom half of all specifications for all three of the meta-statistics. Worst of all are the utilitymaximizing models when it is assumed that the firm manager is risk-neutral. The basic model, with neither capital adjustment costs nor agency problems, also performs poorly. Finally the habit formation, VM-CAC model with low adjustment costs, can clearly be rejected by the data. Five other models, by contrast, are in the top half for each of the three meta-statistics. These include all four of the UM models with risk averse managers, and the VM-CAC model with high capital adjustment costs and a representative household with habit formation utility.

The three models that we have particularly shortlisted for consideration, given their high ability to explain the correlation between dividend and GDP growth, feature in the top three positions according to the total error statistic. They also feature first, second on fifth on the standard deviation error statistic, even 
though their ability to explain volatility was not a criterion for their selection. From this it is clear that including either capital adjustment costs or a value-maximizing risk-averse manager makes a material improvement on the standard economic model across a wide range of metrics covering volatility and covariance. For the UM model, this finding is not particularly sensitive to either the level of risk aversion of the manager (although the low risk aversion manager specification is preferred), or the presence or absence of household habit formation. The UM, mild risk aversion, with habit model is perhaps of particular note as it lies within the top three models for all of the meta-statistics considered.

\subsection{Sensitivity analysis}

In Figures 1 and 2, we explore the sensitivity of dividend cyclicality to the choice of $\gamma_{F}$ and $\zeta$ for different levels of $\gamma$. For the UM model, the results are largely insensitive to $\gamma$. The pro-cyclicality of equity payouts declines steeply with $\gamma_{F}<$ 1.25 , but, above this level, equity payouts quickly become highly pro-cyclical at a relatively steady level. For the VM-CAC model, there is greater sensitivity of the results with respect to $\gamma$, especially when $\zeta<10$. Our baseline calibration value of $\gamma=1.44$ is at the lower end of standard estimates. With higher values of $\gamma$, an even higher capital adjustment cost is required to explain the observed procyclicality of payout policy. 
Insert Figures $1 \& 2$ around here

Results detailing the sensitivity of dividend and consumption procyclicality to a wide range of plausible parameter values are presented in Tables 3 (for the UM model) and 4 (for the VM-CAC model).

\section{Insert Tables $3 \& 4$ around here}

For the UM model with $\gamma_{F}=1.25$, there is relatively low sensitivity of the correlation between dividends and output for most parameters considered $(\alpha, \eta, \xi$, $\mathrm{x}, \rho$ and $\sigma_{\varepsilon}$ ) and aggregate consumption is positively related to output in all cases, with this relationship becoming stronger when the manager becomes more riskaverse $\left(\gamma_{F}=5\right)$. The pro-cyclicality of dividends is, however, sensitive to the stochastic time discount factor $(\beta)$ and the persistence of technology shocks $(\psi)$. As expected, dividends are more pro-cyclical when technology persistence becomes stronger, except potentially in the case of extremely risk averse managers. As the rate of pure time preference increases ( $\beta$ decreases), the relationship between output and dividends becomes less positive.

The VM-CAC model is more sensitive to parameter choices than the UM model. Dividends can become negatively related to output not only with low CAC 
but also in the case of high $\mathrm{CAC}$ in the presence of relatively strong habit persistence or low persistence of technology shocks. In addition, aggregate dividends in the VM-low-CAC model are not as sensitive to parameter choices as in the VM-high-CAC model. Aggregate dividends become less positively related to output when the time discount factor, habit persistence, the elasticity of consumption, and the depreciation rate are high and when the persistence of technology shocks is low.

While we have been able to reconcile observed behavior with general equilibrium using either the UM or VM-CAC models in economies without heterogeneous agents and incomplete markets, we believe that the former is more realistic than the latter. An estimate of $\gamma_{F}=1.25$ is broadly consistent with standard estimates of risk aversion. By contrast, the level of capital adjustment cost implicit in the $\zeta=0.30$ case is very large. Taking as an example a firm that wishes to invest $5 \%$ of new capital into its firm: $I_{t} / K_{t-1}=0.05$. If $\zeta=0.30$, then, from Equation 7 , only $0.0336 K_{t-1}$ makes its way into the firm and the rest is lost to frictions. This means that only two-thirds of the money re-invested becomes effective. With lower levels of CAC, the model has lower explanatory power. Further, the explanatory power is more robust to parameter value changes for the UM model than the VM-CAC model. 


\section{Concluding Remarks}

In this paper we have described two general equilibrium models that explain why external changes in the economic environment result in businesses systematically implementing pro-cyclical equity payout policies. This resolves an anomaly that is present in many previous general equilibrium studies. In addition, our more sophisticated models are able to capture a number of other features of the observed macroeconomy that are poorly captured by a basic DSGE framework.

Our preferred model is based on the assumption that managers maximize their own objective function rather than the share price of their firms. This makes them more reluctant to re-invest in the business in economic booms in case conditions change. More cash can then be paid out when times are good. Even with relatively low levels of managerial risk aversion, the calibrated theoretical model matches the summary statistics of historical data well.

An alternative model that we have analyzed includes capital adjustment costs within an economy where managers maximize their current share price. These frictions also inhibit managers from heavily re-investing in a pro-cyclical manner, and the resultant payout policy moves in line with the economy. However, in this case, the level of capital adjustment costs needs to be high to accurately calibrate the model in a manner that is consistent with the data and therefore we believe this is the less credible explanation of the payout pro-cyclicality anomaly. These 
findings support the idea that agency conflicts play an important role in real business cycle models.

\section{References}

Alessandrini, F., 2003 (February). Introducing capital structure in a production economy: implications for investment, debt and dividends. Financial Valuation and Risk Management Working Paper No. 47.

Alli, K.L., Khan, A.Q., Ramirez, G.G., 1993. Determinants of corporate dividend policy: a factorial analysis. Finan. Rev. 28, 523-547. DOI: http://dx.doi.org/10.1111/j.1540-6288.1993.tb01361.x

An, Y., Cheung, K. 2010. Project financing: Deal or no deal. Rev. Finan. Econ. 19, 72-77. DOI: http://dx.doi.org/10.1016/j.rfe.2009.02.002

Baker, H.K., Smith, D.M., 2006. In search of a residual dividend policy. Rev. Finan. Econ. 15, 1-18. DOI: http://dx.doi.org/10.1016/j.rfe.2004.10.002

Baxer, M., King, R.G., 1999. Measuring business cycles: approximate band-pass filters for economic time series. Rev. Econ. Stat. 81, 575-593. DOI: http://dx.doi.org/10.1162/003465399558454

Bhattacharyya, N., 2007. Dividend policy: a review. Manag. Finan. 33, 4-13. DOI: http://dx.doi.org/10.1108/03074350710715773

Boldrin, M., Christiano, L.J., Fisher, J.D.M., 2001. Habit persistence, asset returns, and the business cycle. Am. Econ. Rev. 91, 149-166. URL: http://www.jstor.org/stable/2677902

Campbell, J.Y., 1994. Inspecting the mechanism: an analytical approach to the stochastic growth model. J. Monet. Econ. 33, 463-506. DOI: http://dx.doi.org/10.1016/0304-3932(94)90040-X 
Canzoneri, M.B., Cumby, R.E., Diba, B.T., 2006 (September). How do monetary and fiscal policy interact in the European monetary union? in NBER International Seminar on Macroeconomics 2004, pp. 241-326. The MIT Press.

Carceles-Poveda, E., 2003. Capital adjustment costs and firm risk aversion. Econ. Lett. 81, 101-107. DOI: http://dx.doi.org/10.1016/S0165-1765(03)00150-2

Carceles-Poveda, E., 2005. Idiosyncratic shocks and asset returns in the realbusiness-cycle model: an approximate analytical approach. Macroecon. Dyn. 9, 295-320. DOI: http://dx.doi.org/10.1017/S1365100505040216

Carceles-Poveda, E., 2009. Asset prices and business cycles under market incompleteness. Rev. Econ. Dyn. 12, 405-422. DOI: http://dx.doi.org/10.1016/j.red.2008.07.004

Carroll, C.D., 2000. Solving consumption models with multiplicative habits. Econ. Lett. 68, 67-77. DOI: http://dx.doi.org/10.1016/S0165-1765(00)00223-8

Carroll, C.D., Overland, J., Weil, D.N., 2000. Saving and growth with habit formation. Am. Econ. Rev. 90, 341-355. URL: http://www.jstor.org/stable/117332

Christiano, L.J., Fisher, J., 1995. Tobin's q and asset returns: implications for business cycle analysis. NBER Working Paper No. 5292. URL: http://www.nber.org/papers/w5292

Collard, F., Dellas, H., 2006. The case for inflation stability. J. Monet. Econ. 53, 1801-1814. DOI: http://dx.doi.org/10.1016/j.jmoneco.2005.09.002

Constantinides, G.M., 1990. Habit formation: a resolution of the equity premium puzzle. J. Polit. Econ. 98, 519-543. URL: http://www.jstor.org/stable/2937698

Cooley, T.F., Prescott, E.C., 1995. Economic growth and business cycles, in: Cooley, T.F. (Eds.), Frontiers of Business Cycle Research. Princeton University Press, pp. 1-38.

Cooper, R.W., Haltiwanger, J.C., 2006. On the nature of capital adjustment costs. Rev. Econ. Stud. 73, 611-633. DOI: http://dx.doi.org/10.1111/j.1467937X.2006.00389.x 
Danthine, J.P., Donaldson, J.B., 2002. Labour relations and asset returns. Rev. Econ. Stud. 69, 41-64. DOI: http://dx.doi.org/10.1111/1467-937X.00197

Dynan, K.E., 2000. Habit formation in consumer preferences: evidence from panel data. Am. Econ. Rev. 90, 391-406. URL: http://www.jstor.org/stable/117335

Gershun, N., 2010. Habit persistence, impediments to production factor adjustments, and asset returns in general equilibrium models with self-fulfilling expectations. Rev. Finan. Econ. 19, 19-27. DOI: http://dx.doi.org/10.1016/j.rfe.2009.08.001

Hansen, G.D., 1985. Indivisible labor and the business cycle. J. Monet. Econ. 16, 309-327. DOI: http://dx.doi.org/10.1016/0304-3932(85)90039-X

Heaton, J., Lucas, D., 2000. Portfolio choice and asset prices: the importance of $\begin{array}{lllll}\text { entrepreneurial } & \text { risk. } & \text { J. } & \text { Finan. }\end{array}$ DOI: http://dx.doi.org/10.1111/0022-1082.00244

Jermann, U.J., 1998. Asset pricing in production economies. J. Monet. Econ. 41, 257-275. DOI: http://dx.doi.org/10.1016/S0304-3932(97)00078-0

Jermann, U., Quadrini, V., 2012. Macroeconomic effects of financial shocks. Am. Econ. Rev. 102, 238-271. DOI: http://dx.doi.org/10.1257/aer.102.1.238

Kydland, F.E., Prescott, E.C., 1982. Time to build and aggregate fluctuations. Econom. 50, 1345-1370. URL: http://www.jstor.org/stable/1913386

Lang, L.H.P., Litzenberger, R.H., 1989. Dividend announcements: Cash flow signalling vs. free cash flow hypothesis? J. Finan. Econ. 24, 181-191. DOI: http://dx.doi.org/10.1016/0304-405X(89)90077-9

Leland, H.E., 1972. Theory of the firm facing uncertain demand. Am. Econ. Rev. 62, 278-291. URL: http://www.jstor.org/stable/1803376

Ljungqvist, L. Sargent, T.J., 2004. Recursive Macroeconomic Theory. The MIT Press, Cambridge, MA.

Mehra, R., Prescott, E.C., 1985. The equity premium: a puzzle. J. Monet. Econ. 15, 145-161. DOI: http://dx.doi.org/10.1016/0304-3932(85)90061-3 
Otrok, C., B. Ravikumar, B., Whiteman, C., 2002. Habit formation: a resolution of the equity premium puzzle? J. Monet. Econ. 49, 1261-1288. DOI: http://dx.doi.org/10.1016/S0304-3932(02)00147-2

Parrino, R., Poteshman, A.M., Weisbach, M.S., 2005. Measuring investment distortions when risk-averse managers decide whether to undertake risky projects. Finan. Manag. 34, 21-60. DOI: http://dx.doi.org/10.1111/j.1755053X.2005.tb00091.x

Prescott, E.C., 1986. Theory ahead of business cycle measurement. Federal Reserve Bank of Minneapolis Quarterly Review (Fall), 9-22.

Radner, R., 1970. Problems in the theory of markets under uncertainty. Am. Econ. Rev. 60, 454-460. URL: http://www.jstor.org/stable/1815845

Sandmo, A., 1971. On the theory of the competitive firm under price uncertainty. Am. Econ. Rev. 61, 65-73. URL: http://www.jstor.org/stable/1910541

Santoro, M., Wei, C., 2011. Taxation, investment and asset pricing. Rev. Econ. Dyn. 14, 443-454. DOI: http://dx.doi.org/10.1016/j.red.2010.09.002

Seckin, A., 2001. Consumption-leisure choice with habit formation. Econ. Lett. 70, 115-120. DOI: http://dx.doi.org/10.1016/S0165-1765(00)00330-X 


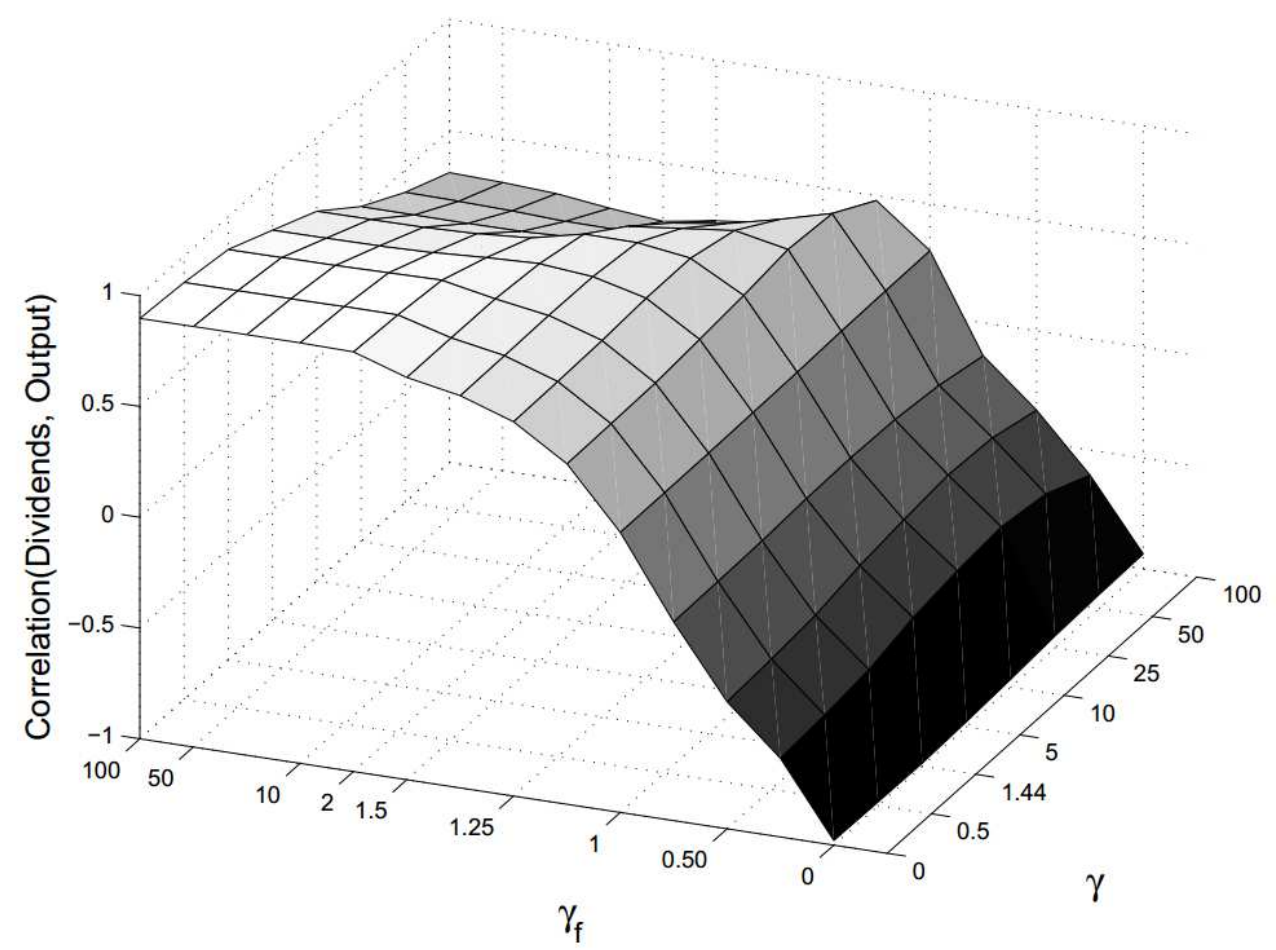

Fig. 1. The correlation ( $\mathrm{Z}$ axis) between equity payouts and output growth in the utility-maximization (UM) model across various levels of risk aversion of the firm, $\gamma_{F}$ ( $\mathrm{X}$ axis) and the household, $\gamma$ ( $\mathrm{Y}$ axis). The value of risk aversion ranges from zero (risk-neutral) to one hundred (extremely risk-averse). 


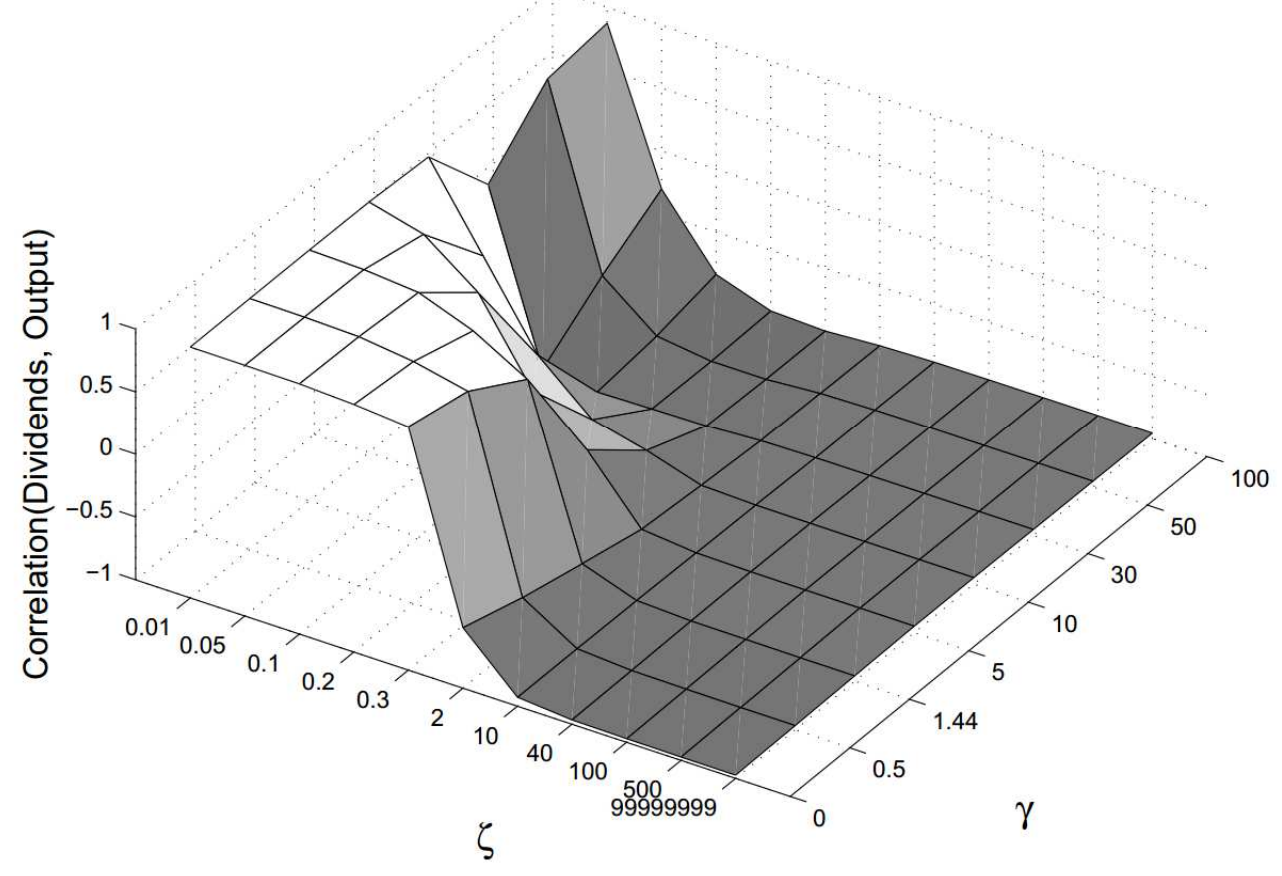

Fig. 2. The correlation ( $\mathrm{Z}$ axis) between equity payouts and output growth in the value maximization (VM-CAC) model across various levels of capital adjustment costs ( $\mathrm{X}$ axis) and risk aversion of the household, $\gamma(\mathrm{Y}$ axis). The variable $\zeta$ on the $\mathrm{X}$ axis determines the level of capital adjustment costs; the lower the value of $\zeta$, the higher the costs. 


\section{Table 1}

Modeled and observed summary statistics for the macroeconomy

\begin{tabular}{|c|c|c|c|c|c|c|c|c|c|c|c|c|c|}
\hline \multirow{3}{*}{$\begin{array}{l}\text { With/without habit } \\
\text { Model type }\end{array}$} & \multicolumn{2}{|c|}{ Baseline Models } & \multicolumn{10}{|c|}{ Advanced Specifications } & \multirow[b]{3}{*}{$\begin{array}{c}\text { US } \\
\text { Data }^{a}\end{array}$} \\
\hline & \multirow{2}{*}{$\begin{array}{c}\text { No } \\
\text { Habit } \\
\\
\text { VM }\end{array}$} & \multirow{2}{*}{$\begin{array}{l}\text { Habit } \\
\text { VM }\end{array}$} & \multicolumn{5}{|c|}{ No Habit } & \multicolumn{5}{|c|}{ Habit } & \\
\hline & & & $\mathrm{UM}$ & $\mathrm{UM}$ & $\mathrm{UM}$ & $\begin{array}{l}\text { VM- } \\
\text { CAC }\end{array}$ & $\begin{array}{l}\text { VM- } \\
\text { CAC }\end{array}$ & $\mathrm{UM}$ & $\mathrm{UM}$ & $\mathrm{UM}$ & $\begin{array}{l}\text { VM- } \\
\text { CAC }\end{array}$ & $\begin{array}{l}\text { VM- } \\
\text { CAC }\end{array}$ & \\
\hline \multirow[t]{2}{*}{$\begin{array}{l}\text { Model } \\
\text { specification }\end{array}$} & $\begin{array}{l}\text { No- } \\
\text { CAC }\end{array}$ & $\begin{array}{l}\text { No- } \\
\text { CAC }\end{array}$ & $\begin{array}{c}\text { Risk } \\
\text { Neutral }\end{array}$ & $\begin{array}{c}\text { Mild } \\
\text { risk- } \\
\text { averse } \\
\left(\gamma_{F}=1.25\right)\end{array}$ & $\begin{array}{l}\text { Strong } \\
\text { risk- } \\
\text { averse } \\
\left(\gamma_{\mathrm{F}}=5\right)\end{array}$ & $\begin{array}{c}\text { Low } \\
\text { CAC } \\
(\zeta=40)\end{array}$ & $\begin{array}{c}\text { High } \\
\text { CAC } \\
(\zeta=0.30)\end{array}$ & $\begin{array}{c}\text { Risk } \\
\text { Neutral }\end{array}$ & $\begin{array}{c}\text { Mild } \\
\text { risk- } \\
\text { averse } \\
\left(\gamma_{\mathrm{F}}=1.25\right)\end{array}$ & $\begin{array}{l}\text { Strong } \\
\text { risk- } \\
\text { averse } \\
\left(\gamma_{\mathrm{F}}=5\right)\end{array}$ & $\begin{array}{l}\text { Low } \\
\text { CAC } \\
(\zeta=40)\end{array}$ & $\begin{array}{c}\text { High } \\
\text { CAC } \\
(\zeta=0.30)\end{array}$ & $\begin{array}{c}(1984: 1 \\
- \\
\text { 2010:2) }\end{array}$ \\
\hline & (1) & (2) & (3) & (4) & (5) & $(6)$ & (7) & (8) & (9) & $(10)$ & (11) & $(12)$ & \\
\hline \multicolumn{14}{|c|}{ Correlation with GDP } \\
\hline Dividends & -0.98 & -0.96 & -0.95 & 0.50 & 0.90 & -0.98 & 1.00 & -0.99 & 0.55 & 0.86 & -0.95 & 0.55 & 0.50 \\
\hline Consumption & 0.94 & 0.51 & -0.85 & 1.00 & 1.00 & 0.96 & 1.00 & -0.08 & 1.00 & 1.00 & 0.55 & 0.97 & 0.97 \\
\hline Hours worked & 0.98 & 0.98 & 0.96 & 0.99 & 1.00 & 0.99 & -1.00 & 0.97 & -0.23 & -0.22 & 0.98 & -0.56 & 0.84 \\
\hline Investment & 0.99 & 0.98 & 0.97 & 1.00 & 1.00 & 0.99 & 1.00 & 0.99 & 1.00 & 1.00 & 0.98 & 0.78 & 0.88 \\
\hline \multicolumn{14}{|l|}{ Standard deviation } \\
\hline Dividends & 3.87 & 5.47 & 14.08 & 0.12 & 0.08 & 3.52 & 2.39 & 6.35 & 0.14 & 0.10 & 5.36 & 2.18 & 1.30 \\
\hline Consumption & 0.35 & 0.26 & 1.18 & 0.87 & 0.87 & 0.41 & 1.19 & 0.15 & 0.87 & 0.87 & 0.27 & 1.06 & 1.92 \\
\hline Hours worked & 0.46 & 0.41 & 1.41 & 0.09 & 0.09 & 0.42 & 0.13 & 1.45 & 1.86 & 1.89 & 0.36 & 1.83 & 1.56 \\
\hline Investment & 2.95 & 3.58 & 7.04 & 1.38 & 1.38 & 2.81 & 0.44 & 3.96 & 1.37 & 1.37 & 3.53 & 1.18 & 5.99 \\
\hline
\end{tabular}

Note: This table shows the predicted values of (i) the correlation between the growth of each variable (dividends, consumption, hours worked and investment) and GDP growth, (ii) the standard deviation of each variable, normalized by GDP and (iii) the observed value of each variable from the US economy.

${ }^{\text {a }}$ See notes to Footnote 10. 


\section{Table 2}

Meta-statistics on model performance

\begin{tabular}{|c|c|c|c|c|c|c|c|c|}
\hline Model & Snecification & Habit? & Correlation & $\begin{array}{c}\text { Standard } \\
\text { Dev } \\
\text { Error }\end{array}$ & Total & Correlation & Standard Dev & Total \\
\hline $\mathrm{UM}$ & Mild risk-aversion & No habit & 0.076 & 0.793 & 0.435 & 1 & 5 & 1 \\
\hline VM-CAC & High CAC & Habit & 0.388 & 0.524 & 0.456 & 4 & 1 & 2 \\
\hline UM & Mild risk-aversion & Habit & 0.318 & 0.601 & 0.459 & 3 & 2 & 3 \\
\hline UM & Strong risk-aversion & No habit & 0.178 & 0.801 & 0.489 & 2 & 6 & 4 \\
\hline UM & Strong risk-aversion & Habit & 0.393 & 0.612 & 0.503 & 5 & 3 & 5 \\
\hline VM-CAC & Low CAC & No habit & 0.436 & 0.938 & 0.687 & 6 & 7 & 6 \\
\hline VM-CAC & High CAC & No habit & 0.622 & 0.764 & 0.693 & 10 & 4 & 7 \\
\hline Basic (VM No-CAC) & & No habit & 0.440 & 1.003 & 0.722 & 7 & 8 & 8 \\
\hline VM-CAC & Low CAC & Habit & 0.528 & 1.289 & 0.908 & 8 & 9 & 9 \\
\hline Basic (VM No-CAC) & & Habit & 0.540 & 1.303 & 0.921 & 9 & 10 & 10 \\
\hline UM & Risk Neutral & Habit & 0.697 & 1.305 & 1.001 & 11 & 11 & 11 \\
\hline UM & Risk Neutral & No habit & 0.869 & 2.622 & 1.746 & 12 & 12 & 12 \\
\hline
\end{tabular}

Note: This table reports each model's performance by ranking correlation errors, standard deviation errors and total errors of all models. 
Table 3

Sensitivity analysis for UM model

$$
\gamma_{F}=1.25
$$

$\gamma_{F}=5$

$\beta\left(\beta_{F}\right)$ (the stochastic time discount factor)

\begin{tabular}{|c|c|c|c|c|c|c|c|c|c|c|c|c|}
\hline & 0.100 & 0.500 & 0.985 & 0.990 & 0.995 & 0.999 & 0.100 & 0.500 & 0.985 & 0.990 & 0.995 & 0.999 \\
\hline $\operatorname{corr}(\mathrm{d}, \mathrm{y})$ & 1.00 & 0.97 & 0.59 & 0.55 & 0.46 & 0.29 & 1.00 & 0.97 & 0.86 & 0.86 & 0.84 & 0.49 \\
\hline $\operatorname{corr}(\mathrm{c}, \mathrm{y})$ & 1.00 & 1.00 & 1.00 & 1.00 & 1.00 & 1.00 & 1.00 & 1.00 & 1.00 & 1.00 & 1.00 & 1.00 \\
\hline
\end{tabular}

$\alpha$ (output elasticity of capital)

\begin{tabular}{|c|c|c|c|c|c|c|c|c|c|c|c|c|}
\hline & 0.09 & 0.25 & 0.36 & 0.50 & 0.60 & 0.65 & 0.09 & 0.25 & 0.36 & 0.50 & 0.60 & 0.65 \\
\hline corr & 0.50 & 0.52 & 0.55 & 0.58 & 0.61 & 0.63 & 0.84 & 0.85 & 0.86 & 0.87 & 0.88 & 0.88 \\
\hline $\operatorname{corr}(\mathrm{c}, \mathrm{y})$ & 1.00 & 1.00 & 1.00 & 1.00 & 1.00 & 1.00 & 1.00 & 1.00 & 1.00 & 1.00 & 1.00 & 1.00 \\
\hline
\end{tabular}

$\mathrm{x}$ (the quarterly trend growth rate of effective labor)

\begin{tabular}{|c|c|c|c|c|c|c|c|c|c|c|c|c|}
\hline & 1.00 & 1.005 & 1.50 & 2.00 & 3.00 & 5.00 & 1.00 & 1.005 & 1.50 & 2.00 & 3.00 & 5.00 \\
\hline $\operatorname{corr}(\mathrm{d}, \mathrm{y})$ & 0.55 & 0.55 & 0.55 & 0.55 & 0.55 & 0.55 & 0.86 & 0.86 & 0.86 & 0.86 & 0.86 & 0.86 \\
\hline $\operatorname{corr}(\mathrm{c}, \mathrm{y})$ & 1.00 & 1.00 & 1.00 & 1.00 & 1.00 & 1.00 & 1.00 & 1.00 & 1.00 & 1.00 & 1.00 & 1.00 \\
\hline
\end{tabular}

$\eta$ (the depreciation rate, note that we assume the calibration is in a quarterly model)

\begin{tabular}{|c|c|c|c|c|c|c|c|c|c|c|c|c|}
\hline Annual rate & 0.010 & 0.050 & 0.100 & 0.150 & 0.200 & 0.400 & 0.010 & 0.050 & 0.100 & 0.150 & 0.200 & 0.400 \\
\hline Quarterly rate & 0.003 & 0.013 & 0.025 & 0.038 & 0.050 & 0.100 & 0.003 & 0.013 & 0.025 & 0.038 & 0.050 & 0.100 \\
\hline $\operatorname{corr}(\mathrm{d}, \mathrm{y})$ & 0.63 & 0.57 & 0.55 & 0.54 & 0.56 & 0.65 & 0.83 & 0.85 & 0.86 & 0.87 & 0.87 & 0.88 \\
\hline $\operatorname{corr}(\mathrm{c}, \mathrm{y})$ & 1.00 & 1.00 & 1.00 & 1.00 & 1.00 & 1.00 & 1.00 & 1.00 & 1.00 & 1.00 & 1.00 & 1.00 \\
\hline
\end{tabular}

$\psi$ (the persistence of time-series technology shocks)

\begin{tabular}{|c|c|c|c|c|c|c|c|c|c|c|c|c|}
\hline & 0.00 & 0.05 & 0.80 & 0.95 & 0.98 & 1.00 & 0.00 & 0.05 & 0.80 & 0.95 & 0.98 & 1.00 \\
\hline $\operatorname{corr}(\mathrm{d}, \mathrm{y})$ & 0.33 & 0.33 & 0.37 & 0.55 & 0.73 & 0.82 & 0.53 & 0.53 & 0.73 & 0.86 & 0.80 & 0.61 \\
\hline $\operatorname{corr}(\mathrm{c}, \mathrm{y})$ & 1.00 & 1.00 & 1.00 & 1.00 & 1.00 & 1.00 & 1.00 & 1.00 & 1.00 & 1.00 & 1.00 & 0.98 \\
\hline$\sigma_{\varepsilon}$ & 0.001 & 0.003 & 0.00712 & 0.010 & 0.025 & 0.100 & 0.001 & 0.003 & 0.00712 & 0.010 & 0.025 & 0.100 \\
\hline $\operatorname{corr}(\mathrm{d}, \mathrm{y})$ & 0.55 & 0.55 & 0.55 & 0.55 & 0.55 & 0.55 & 0.86 & 0.86 & 0.86 & 0.86 & 0.86 & 0.86 \\
\hline $\operatorname{corr}(\mathrm{c}, \mathrm{y})$ & 1.00 & 1.00 & 1.00 & 1.00 & 1.00 & 1.00 & 1.00 & 1.00 & 1.00 & 1.00 & 1.00 & 1.00 \\
\hline
\end{tabular}

$\xi$ (habit persistence)

\begin{tabular}{|c|c|c|c|c|c|c|c|c|c|c|c|c|}
\hline & 0.00 & 0.25 & 0.50 & 0.82 & 0.90 & 0.99 & 0.00 & 0.25 & 0.50 & 0.82 & 0.90 & 0.99 \\
\hline $\operatorname{corr}(\mathrm{d}, \mathrm{y})$ & 0.50 & 0.50 & 0.53 & 0.55 & 0.58 & 0.56 & 0.90 & 0.91 & 0.92 & 0.86 & 0.75 & 0.30 \\
\hline $\operatorname{corr}(\mathrm{c}, \mathrm{y})$ & 1.00 & 1.00 & 1.00 & 1.00 & 1.00 & 1.00 & 1.00 & 1.00 & 1.00 & 1.00 & 1.00 & 1.00 \\
\hline
\end{tabular}

$\rho$ (time devoted to provide labor)

\begin{tabular}{|c|c|c|c|c|c|c|c|c|c|c|c|c|}
\hline & 0.05 & 0.25 & 0.36 & 0.50 & 0.75 & 0.99 & 0.05 & 0.25 & 0.36 & 0.50 & 0.75 & 0.99 \\
\hline $\operatorname{corr}(\mathrm{d}, \mathrm{y})$ & 0.55 & 0.55 & 0.55 & 0.54 & 0.54 & 0.51 & 0.84 & 0.85 & 0.86 & 0.87 & 0.90 & 0.91 \\
\hline $\operatorname{corr}(\mathrm{c}, \mathrm{y})$ & 1.00 & 1.00 & 1.00 & 1.00 & 1.00 & 1.00 & 1.00 & 1.00 & 1.00 & 1.00 & 1.00 & 1.00 \\
\hline
\end{tabular}

Note: This table reports the correlations of the growth of dividends and consumption with GDP growth by varying the range of the parameter values for the UM model. 


\section{Table 4}

Sensitivity analysis for VM-CAC model

$$
\zeta=40
$$

$\zeta=0.30$

$\beta\left(\beta_{F}\right)$ (the stochastic time discount factor)

\begin{tabular}{|c|c|c|c|c|c|c|c|c|c|c|c|c|}
\hline & 0.900 & 0.970 & 0.985 & 0.990 & 0.995 & 0.999 & 0.900 & 0.970 & 0.985 & 0.990 & 0.995 & 0.999 \\
\hline $\operatorname{corr}(\mathrm{d}, \mathrm{y})$ & -0.42 & -0.87 & -0.93 & -0.95 & -0.97 & -0.98 & 0.99 & 0.88 & 0.69 & 0.55 & 0.32 & 0.06 \\
\hline $\operatorname{corr}(\mathrm{c}, \mathrm{y})$ & 0.77 & 0.60 & 0.56 & 0.55 & 0.54 & 0.53 & 1.00 & 0.99 & 0.98 & 0.97 & 0.96 & 0.94 \\
\hline
\end{tabular}

$\alpha$ (output elasticity of capital)

$\operatorname{corr}(\mathrm{d}, \mathrm{y})$

\begin{tabular}{rrrrrr}
0.10 & 0.25 & $\mathbf{0 . 3 6}$ & 0.50 & 0.60 & 0.65 \\
\hline-0.89 & -0.94 & $\mathbf{- 0 . 9 5}$ & -0.95 & -0.95 & -0.95 \\
0.66 & 0.58 & $\mathbf{0 . 5 5}$ & 0.52 & 0.50 & 0.49
\end{tabular}

\begin{tabular}{llllll}
0.10 & 0.25 & $\mathbf{0 . 3 6}$ & 0.50 & 0.60 & 0.65 \\
\hline 0.61 & 0.57 & $\mathbf{0 . 5 5}$ & 0.53 & 0.54 & 0.55 \\
1.00 & 0.99 & $\mathbf{0 . 9 7}$ & 0.94 & 0.91 & 0.90
\end{tabular}

$\mathrm{x}$ (the quarterly trend growth rate of effective labor)

$\operatorname{corr}(\mathrm{d}, \mathrm{y})$
$\operatorname{corr}(\mathrm{c}, \mathrm{y})$

\begin{tabular}{rrrrrr}
1.00 & $\mathbf{1 . 0 0 5}$ & 1.50 & 2.00 & 3.00 & 5.00 \\
\hline-0.95 & $\mathbf{- 0 . 9 5}$ & -0.95 & -0.95 & -0.95 & -0.95 \\
0.55 & $\mathbf{0 . 5 5}$ & 0.55 & 0.55 & 0.55 & 0.55
\end{tabular}

\begin{tabular}{rrrrrr}
1.00 & $\mathbf{1 . 0 0 5}$ & 1.50 & 2.00 & 3.00 & 5.00 \\
\hline 0.55 & $\mathbf{0 . 5 5}$ & 0.55 & 0.55 & 0.55 & 0.55 \\
0.97 & $\mathbf{0 . 9 7}$ & 0.97 & 0.97 & 0.97 & 0.97
\end{tabular}

$\eta$ (the depreciation rate, note that we assume the calibration is in a quarterly model)

Quarterly rate

0.10

$0.15 \quad 0.20$

$0.40 \quad 0.60$

$\begin{array}{lll}0.06 & \mathbf{0 . 1 0} & 0.15\end{array}$

corr $(\mathrm{d}, \mathrm{y})$

\begin{tabular}{rrrrrr}
0.015 & $\mathbf{0 . 0 2 5}$ & 0.038 & 0.050 & 0.100 & 0.150 \\
\hline-0.96 & $\mathbf{- 0 . 9 5}$ & -0.93 & -0.91 & -0.84 & -0.78 \\
0.54 & $\mathbf{0 . 5 5}$ & 0.57 & 0.60 & 0.70 & 0.78
\end{tabular}

\begin{tabular}{rrrrrr}
0.015 & $\mathbf{0 . 0 2 5}$ & 0.038 & 0.050 & 0.100 & 0.150 \\
\hline 0.70 & $\mathbf{0 . 5 5}$ & 0.42 & 0.35 & 0.23 & 0.19
\end{tabular}

$\operatorname{corr}(\mathrm{c}, \mathrm{y})$

$0.54 \quad \mathbf{0 . 5 5}$

$0.57 \quad 0.60$

$0.98 \quad \mathbf{0 . 9 7}$

$\begin{array}{llll}0.97 & 0.97 & 0.97 & 0.98\end{array}$

$\psi$ (the persistence of time-series technology shocks)

$\operatorname{corr}(\mathrm{d}, \mathrm{y})$

\begin{tabular}{rrrrrr}
0.00 & 0.05 & 0.80 & $\mathbf{0 . 9 5}$ & 0.98 & 1.00 \\
\hline-1.00 & -1.00 & -0.99 & $\mathbf{- 0 . 9 5}$ & -0.92 & -0.85 \\
0.19 & 0.18 & 0.34 & $\mathbf{0 . 5 5}$ & 0.61 & 0.67
\end{tabular}

\begin{tabular}{rrrrrr}
0.00 & 0.05 & 0.80 & $\mathbf{0 . 9 5}$ & 0.98 & 1.00 \\
\hline-0.97 & -0.93 & -0.09 & $\mathbf{0 . 5 5}$ & 0.62 & 0.62
\end{tabular}

$\operatorname{corr}(\mathrm{c}, \mathrm{y})$

$0.73 \quad 0.77$

0.94

$\mathbf{0 . 9 7} 0.97$

0.97

$\sigma_{\varepsilon}$

$\operatorname{corr}(\mathrm{d}, \mathrm{y})$

\begin{tabular}{rrrrrr}
0.001 & 0.003 & $\mathbf{0 . 0 0 7 1 2}$ & 0.010 & 0.025 & 0.100 \\
\hline-0.95 & -0.95 & $\mathbf{- 0 . 9 5}$ & 0.95 & -0.95 & -0.95 \\
0.55 & 0.55 & $\mathbf{0 . 5 5}$ & 0.55 & 0.55 & 0.55
\end{tabular}

\begin{tabular}{rrrrrr}
0.001 & 0.003 & $\mathbf{0 . 0 0 7 1 2}$ & 0.010 & 0.025 & 0.100 \\
\hline 0.55 & 0.55 & $\mathbf{0 . 5 5}$ & 0.55 & 0.55 & 0.55 \\
0.97 & 0.97 & $\mathbf{0 . 9 7}$ & 0.97 & 0.97 & 0.97
\end{tabular}

$\xi$ (habit persistence)

$\operatorname{corr}(\mathrm{d}, \mathrm{y})$

\begin{tabular}{rrrrrr}
0.00 & 0.25 & 0.50 & $\mathbf{0 . 8 2}$ & 0.90 & 0.99 \\
\hline-0.98 & -0.96 & -0.95 & $\mathbf{- 0 . 9 5}$ & -0.97 & -1.00 \\
0.96 & 0.93 & 0.85 & $\mathbf{0 . 5 5}$ & 0.39 & 0.10
\end{tabular}

\begin{tabular}{rrrrrr}
0.00 & 0.25 & 0.50 & $\mathbf{0 . 8 2}$ & 0.90 & 0.99 \\
\hline 1.00 & 1.00 & 0.96 & $\mathbf{0 . 5 5}$ & -0.03 & -0.99 \\
1.00 & 1.00 & 1.00 & $\mathbf{0 . 9 7}$ & 0.91 & 0.29
\end{tabular}

$\rho$ (time devoted to provide labor)

$\operatorname{corr}(\mathrm{d}, \mathrm{y})$

\begin{tabular}{rrrrrr}
0.05 & 0.25 & $\mathbf{0 . 3 6}$ & 0.50 & 0.75 & 0.99 \\
\hline-0.96 & -0.95 & $\mathbf{- 0 . 9 5}$ & -0.95 & -0.95 & -0.95 \\
0.52 & 0.54 & $\mathbf{0 . 5 5}$ & 0.55 & 0.56 & 0.55
\end{tabular}

\begin{tabular}{llllll}
0.05 & 0.25 & $\mathbf{0 . 3 6}$ & 0.50 & 0.75 & 0.99 \\
\hline 0.74 & 0.62 & $\mathbf{0 . 5 5}$ & 0.44 & 0.21 & -0.20 \\
0.98 & 0.98 & $\mathbf{0 . 9 7}$ & 0.96 & 0.95 & 0.90 \\
\hline
\end{tabular}


Note: This table reports the correlations of the growth of dividends and consumption with GDP growth by varying the range of the parameter values for the VM-CAC model. 